\title{
Szumy uszne u dzieci
} Tinnitus in children

\section{Danuta Raj-Koziak ${ }^{1 \mathrm{ADEF}}$, Katarzyna Bieńkowska ${ }^{1 \mathrm{EF}}$, Henryk Skarżyński ${ }^{1 \mathrm{AD}}$, Piotr H. Skarżyński ${ }^{1,2,3 D E}$}

${ }^{1}$ Instytut Fizjologii i Patologii Słuchu, Światowe Centrum Słuchu, Warszawa/Kajetany

${ }^{2}$ Warszawski Uniwersytet Medyczny, II Wydział Lekarski, Zakład Niewydolności Serca i Rehabilitacji Kardiologicznej, Warszawa

${ }^{3}$ Instytut Narządów Zmysłów, Kajetany

\section{Streszczenie}

Cel: Celem pracy była ocena problemu, jaki stanowią szumy uszne u dzieci.

Materiał i metoda: Na podstawie przeglądu piśmiennictwa oraz doświadczeń własnych przeprowadzono analizy na temat: rodzaju szumów usznych, przyczyn ich występowania, epidemiologii oraz zależności pomiędzy występowaniem szumów usznych a płcią, wiekiem dziecka oraz współistniejącym niedosłuchem.

Wyniki: Szeroki rozrzut wyników badań epidemiologicznych uniemożliwia zajęcie jednoznacznego stanowiska w kwestii częstości występowania szumów usznych u dzieci. Częstość występowania tej dolegliwości wśród dzieci wzrasta wraz z wiekiem. Szumy uszne mogą wpływać negatywnie na jakość życia dziecka, powodując problemy ze snem oraz zaburzenia lękowe i depresyjne. Obecność szumów usznych istotnych klinicznie mogłaby być kryterium kwalifikującym dzieci do dalszej diagnostyki, natomiast ich podział na dokuczliwe i niedokuczliwe mógłby stanowić kryterium kwalifikujące do terapii. Pytanie o obecność szumów usznych powinno zostać włączone do rutynowego wywiadu klinicznego, zbieranego od dziecka powyżej 6 roku życia.

Wnioski: Szumy uszne dziecięce wymagają opracowania jednolitego, przyjaznego dziecku i jego rodzicom, powszechnie obowiązującego schematu postępowania diagnostycznego i terapeutycznego.

Słowa kluczowe: szumy uszne • nadwrażliwość słuchowa • niedosłuch • dzieci

\section{Abstract}

Aim: The aim of this article is to present the problem of tinnitus in children.

Material and method: The results are based on review of the literature and professional experience. Type of tinnitus, etiology and epidemiology were analyzed. Relationship between tinnitus and gender, child's age, hearing loss were also assessed.

Results: The wide spread of the results of epidemiological studies makes it impossible to take an unequivocal position on the prevalence of tinnitus in children. The incidence of this ailment among children increases with age. Tinnitus may affect the quality of life of the child, causing sleep problems and anxiety and depression. The presence of clinically significant tinnitus could be a criterion for qualifying children for further diagnosis, while their division into annoying and uncomfortable could be a qualifying criterion for therapy. The question about the presence of tinnitus should be included in routine clinical history, collected from a child over 6 years of age. Conclusions: Tinnitus present in children requires the development of a uniform and universally applicable diagnostic and therapeutic procedure, which would be friendly both for children and their parents.

Key words: tinnitus $\bullet$ hyperacusis $\bullet$ hearing loss $\bullet$ children

\section{Wprowadzenie}

Z klinicznego punktu widzenia z szumami usznymi wiąże się wiele pytań i wątpliwości. Czy szumy uszne są częstym problemem zgłaszanym przez dzieci lub ich rodziców? W jaki sposób są rozpoznawane? Czy stanowią istotne zagrożenie dla nastolatków? Na te i szereg innych pytań próbują odpowiedzieć specjaliści zajmujący się młodymi pacjentami cierpiącymi z powodu szumów usznych. Liczba publikacji na temat występowania szumów usznych w populacji dziecięcej w porównaniu z liczbą pozycji dotyczących populacji osób dorosłych jest niewielka. 
Przedstawiane wyniki badań różnią się między sobą, szczególnie w zakresie oceny częstości występowania problemu, co dodatkowo utrudnia zajęcie jednoznacznego stanowiska. W Światowym Centrum Słuchu Instytutu Fizjologii i Patologii Słuchu na podstawie przeprowadzonych badań dokonano oceny częstości występowania szumów usznych w populacji dziecięcej oraz wypracowano procedury diagnostyczne i terapeutyczne adresowane do tej grupy pacjentów [1].

\section{Cel}

Celem pracy było przedstawienie obecnego stanu wiedzy oraz piśmiennictwa na temat szumów usznych u dzieci.

\section{Materiał i metoda}

Na podstawie przeglądu piśmiennictwa oraz doświadczeń własnych przeprowadzono analizy dotyczące rodzaju szumów usznych, przyczyn ich występowania, epidemiologii oraz zależności pomiędzy występowaniem szumów usznych a płcią, wiekiem dziecka oraz współistniejącym niedosłuchem.

Przegląd piśmiennictwa polegał na przeanalizowaniu baz danych: SCOPUS, PubMed, Web of Science oraz analizie publikacji zamieszczonych w polskich czasopismach $\mathrm{z}$ listy B Ministerstwa Nauki i Szkolnictwa Wyższego. W wyniku analizy i przeszukania baz danych uzyskano 776 pozycji. Odrzucono pozycje literaturowe, które koncentrowały się na populacji osób dorosłych lub dotyczyły badań na zwierzętach. Ostatecznie analizie poddano 39 publikacji.

\section{Wyniki analizy piśmiennictwa oraz doświadczeń własnych}

\section{Podział oraz przyczyny szumów usznych}

Szumy uszne u dzieci, podobnie jak w grupie dorosłych, można najprościej podzielić na szumy uszne subiektywnie, czyli takie, które słyszy tylko dziecko i nie ma możliwości ich pomiaru za pomocą urządzeń, oraz szumy uszne obiektywne, które mogą być słyszalne i rejestrowane również przez osoby drugie [2,3]. Najczęściej obserwuje się występowanie szumów usznych o charakterze subiektywnym. Szumy uszne obiektywne występują u dzieci, tak jak i u dorosłych, niezwykle rzadko.

Przydatny w diagnostyce szumów usznych u młodych pacjentów może okazać się podział na szumy uszne pierwotne i wtórne, który jest powszechnie stosowany w odniesieniu do osób dorosłych.

Termin 'szumy pierwotne', czyli inaczej idiopatyczne, jest używany dla określenia szumów, które powstały bez uchwytnej przyczyny. Mogą one występować zarówno $\mathrm{u}$ dzieci z niedosłuchem, jak i u dzieci ze słuchem prawidłowym. Szumy uszne wtórne to takie, które spowodowane są konkretną przyczyną, ale uwaga - inną niż niedosłuch, lub też identyfikowalną przyczyną organiczną. Powodem odczuwania szumów usznych wtórnych przez dzieci może być np.: obecność ciała obcego lub woszczyny w przewodzie słuchowym zewnętrznym, choroby ucha środkowego, takie jak np. zaburzenia drożności trąbki słuchowej czy wysiękowe zapalenie ucha środkowego, zaburzenia na poziomie ślimaka, takie jak choroba Meniere’a, czy też patologie pozaślimakowe w obrębie nerwu słuchowego [4]. Częstym powikłaniem nawracających infekcji górnych dróg oddechowych u dzieci jest przewlekłe wysiękowe zapalenie ucha środkowego. Jest to jedno z najczęstszych rozpoznań stawianych przez otolaryngologów oraz audiologów i stanowi jedną z częstszych przyczyn niedosłuchu u dzieci [5,6]. Większość autorów jest zgodna, że istnieje zależność pomiędzy zapaleniem uszu a częstszym występowaniem szumów usznych u dzieci [7-10]. Badania przeprowadzone przez Instytut Fizjologii i Patologii Słuchu wykazały, że ryzyko wystąpienia szumów usznych u dzieci z przebytymi zapaleniami uszu jest prawie trzykrotnie wyższe $\mathrm{w}$ porównaniu $\mathrm{z}$ grupą dzieci, u których $\mathrm{w}$ wywiadzie nie stwierdzono stanów zapalnych uszu w przeszłości. Mahboubi stwierdził większe prawdopodobieństwo wystąpienia szumów usznych u dzieci, które przebyły, co najmniej trzykrotnie, infekcje uszu, oraz u dzieci, u których zastosowano drenaż wentylacyjny jam bębenkowych z powodu wysiękowych zapaleń uszu [10]. Natomiast według Savastano wysiękowe zapalenie ucha środkowego nie wydaje się istotnym czynnikiem ryzyka wystąpienia dziecięcych szumów usznych [11]. Choroba Meniere’a u dzieci występuje rzadko. Akagi stwierdził występowanie tej choroby w $1,1 \%$ przypadków i nie zawsze obecne były wszystkie objawy z triady, obejmujące: zawroty głowy, szumy uszne oraz niedosłuch [12]. Podobnie nerwiaki nerwu słuchowego u dzieci występują niezwykle rzadko. Truy opisał typowe objawy, pod postacią niedosłuchu, szumów usznych, bólów głowy, porażeń N VII, u pięciorga dzieci, w tym u jednego z pacjentów rozpoznano neurofibromatozę typu II [13].

Przyczyny szumów usznych wtórnych, generowanych poza układem słuchowym, to: zaburzenia naczyniowe, mioklonie mięśni podniebienia miękkiego czy mięśnia napinacza błony bębenkowej. Mioklonie podniebienia miękkiego występujące u dzieci opisano dotychczas w niewielu przypadkach [14-17]. Najmłodsze dziecko, u którego zdiagnozowano mioklonie podniebienia, miało 5 lat i samo zgłosiło matce słyszenie w obojgu uszach dźwięków opisywanych jako klikanie. Wyniki wszystkich wykonanych testów, łącznie $\mathrm{z}$ badaniem rezonansu magnetycznego, były prawidłowe. Po roku szumy uszne subiektywne ustąpiły u pacjentasamoistnie [17]. U monozygotycznych bliźniąt płci żeńskiej szumy uszne pod postacią mioklonii podniebienia pojawiły się po raz pierwszy u jednej z bliźniaczek w wieku 14 lat. Druga $\mathrm{z}$ nich mioklonie podniebienia zaobserwowała dopiero w wieku 34 lat [16]. Mioklonie mięśnia napinacza błony bębenkowej wystąpiły u 11-letniego chłopca, który zgłaszał rytmiczne klikania w obojgu uszach. Mioklonie mięśnia napinacza błony bębenkowej powodowały ruchy błony bębenkowej synchroniczne ze słyszeniem szumów usznych [18].

Inny podział szumów, ważny z klinicznego punktu widzenia, to podział na szumy istotne i nieistotne klinicznie. W badaniach własnych jako kryterium istotności klinicznej szumów usznych przyjęto czas ich trwania powyżej 5 minut $[1,19]$. Podobne kryterium istotności klinicznej odczuwanych szumów usznych zastosował Mahboubi [10]. Ocena istotności klinicznej odczuwanych szumów usznych pod względem czasu trwania stosowana jest najczęściej 
w pracach epidemiologicznych. W publikacjach koncentrujących się na strategiach pomocy pacjentom preferowane jest raczej określenie istotności klinicznej szumów usznych, które związane są ze stopniem ich dokuczliwości. Humphriss do oceny istotności klinicznej odczuwanych szumów usznych zastosowała dwa kryteria: czas trwania (dłużej niż sekundy) oraz dokuczliwość (nawet niewielka) odczuwanych szumów usznych [20]. Zdefiniowanie, co oznacza pojęcie 'szumy istotne klinicznie', wydaje się kluczowe, gdyż jest to kryterium kwalifikujące dzieci z szumami usznymi do dalszej diagnostyki.

Ponadto podział dziecięcych szumów usznych na dokuczliwe i niedokuczliwe może okazać się przydatny w procesie kwalifikacji do dalszego postępowania terapeutycznego. Informacji na temat dokuczliwości szumów usznych odczuwanych przez dzieci jest niewiele, panuje jednak powszechne przekonanie, że szumy uszne u dzieci wykazują pewne podobieństwa do szumów usznych występujących w populacji osób dorosłych. U dzieci, podobnie jak u osób starszych, szumy uszne są przyczyną odczuwania lęku, strachu czy nawet depresji. Szpitalna Skala Lęku i Depresji (Hospital Anxiety and Depressive Scale), zaadaptowana do oceny występowania zaburzeń lękowych i depresyjnych u dzieci, została wykorzystana przez Holgers. Stwierdziła ona, że 33\% dzieci z szumami usznymi miało możliwe lub prawdopodobne zaburzenia emocjonalno-lękowe. Według tej samej autorki grupa 14,5\% dzieci miała - na podstawie kryteriów oceny zaproponowanych przez White - prawdopodobne lub możliwe objawy depresji [21]. W badaniach własnych stwierdzono, że $50 \%$ dzieci odczuwających szumy stałe oraz 29,2\% dzieci doświadczających szumów okresowych odczuwa $\mathrm{z}$ ich powodu lęk [1]. Kentish opisał profil psychologiczny małego dobrze słyszącego pacjenta $\mathrm{z}$ dokuczliwymi szumami usznymi - dzieci z prawidłowym progiem słyszenia odczuwały większy poziom niepokoju z powodu szumów usznych w porównaniu $\mathrm{z}$ dziećmi $\mathrm{z}$ niedosłuchem współistniejącym $\mathrm{z}$ szumami usznymi. Szumy uszne u dzieci mogą powodować problemy emocjonalne, zaburzenia koncentracji oraz stanowić przyczynę uzyskiwania gorszych wyników w nauce [22]. Podobnie jak w grupie osób dorosłych dzieci odczuwające szumy uszne zgłaszają problemy z zasypianiem czy jakością snu. Słyszane przez dziecko dźwięki mogą być przyczyną problemów z zapamiętywaniem w procesie uczenia się i powodować rozdrażnienie $[1,22,23]$.

Ze względu na czas trwania szumów usznych przyjęto podział na szumy uszne stałe i okresowe. Proponowany podział szumów usznych u dzieci przedstawiono w tabeli 1 .

\section{Zgłaszanie szumów usznych przez dzieci}

Większość autorów wyraża pogląd, że zebranie wywiadu z dzieckiem na temat występowania szumów usznych jest trudne ze względu na fakt, że dzieci odpowiadają na pytania w różny sposób. Nie rozumiejąc pytania, mogą chcieć przypodobać się pytającemu i wtedy na wszystkie pytania będą odpowiadać pozytywnie (tzw. overreporting) lub odwrotnie, mogą czuć się zdezorientowane, speszone pytaniami i odpowiadać negatywnie (tzw. underreporting) [24]. Powszechnie wiadomo, że dzieci rzadko spontanicznie zgłaszają słyszenie szumów usznych, ale zapytane o problem potrafią dokładnie opowiedzieć, co odczuwają. Savastano stwierdziła, że spontanicznie szumy uszne zgłosiło 6\% dzieci, natomiast odsetek dzieci odczuwających szumy uszne wzrósł do $34 \%$, gdy zostały one bezpośrednio zapytane o ich słyszenie [11]. Retrospektywna analiza wyników danych ankietowych (zebranych podczas realizacji przez Instytut Fizjologii i Patologii Słuchu w roku 2008 programu przesiewowych badań słuchu wśród dzieci w wieku 7 lat, zamieszkujących małe miasta i wsie $\mathrm{z}$ regionu Polski wschodniej, oraz podczas podobnego programu realizowanego w roku 2010 na terenie Polski zachodniej, gdy przebadano ponad 100 tysięcy dzieci), wykazała, że dziecko w wieku 6 czy 7 lat potrafi wiarygodnie odpowiedzieć na pytanie o odczuwanie szumów usznych. Savastano uważa, że rzetelne wyniki uzyskała od dzieci nieco starszych, tzn. w wieku 8 lat [11]. Rozbieżność pomiędzy częstym

Tabela 1. Klasyfikacja szumów usznych

Table 1. Classification of tinnitus

\begin{tabular}{|c|c|}
\hline \multicolumn{2}{|c|}{ Podział szumów usznych } \\
\hline $\begin{array}{l}\text { Szumy uszne subiektywne } \\
\text { Objective tinnitus }\end{array}$ & $\begin{array}{c}\text { Szumy styszane tylko przez dziecko, nie ma możliwości ich pomiaru } \\
\text { za pomocą urządzeń zewnętrznych }\end{array}$ \\
\hline $\begin{array}{l}\text { Szumy uszne obiektywne } \\
\text { Subjective tinnitus }\end{array}$ & $\begin{array}{l}\text { Szumy styszane i rejestrowane zarówno przez dziecko, } \\
\text { jak i osoby drugie }\end{array}$ \\
\hline $\begin{array}{l}\text { Szumy uszne pierwotne } \\
\text { Primary tinnitus }\end{array}$ & $\begin{array}{l}\text { Szumy tzw. idiopatyczne, które powstały bez uchwytnej przyczyny, } \\
\text { mogą występować zarówno u dzieci prawidłowo słyszących, } \\
\text { jak i u dzieci niedosłuchem }\end{array}$ \\
\hline $\begin{array}{l}\text { Szumy uszne wtórne } \\
\text { Secondary tinnitus }\end{array}$ & $\begin{array}{c}\text { Szumy spowodowane konkretną przyczyną w układzie słuchowym } \\
\text { lub pozasłuchowym, ale uwaga - inną niż niedosłuch, lub } \\
\text { identyfikowalną przyczyną organiczną }\end{array}$ \\
\hline $\begin{array}{l}\text { Dokuczliwe szumy uszne } \\
\text { Bothersome tinnitus }\end{array}$ & $\begin{array}{l}\text { Szumy uszne negatywnie wpływające na jakość życia pacjenta, } \\
\text { powodujące problemy emocjonalne, zaburzenia lękowe, problemy }\end{array}$ \\
\hline $\begin{array}{l}\text { Niedokuczliwe szumy uszne } \\
\text { Nonbothersome tinnitus }\end{array}$ & Szumy uszne, które nie wpływają na funkcjonowanie dziecka \\
\hline $\begin{array}{l}\text { Szumy uszne istotne klinicznie } \\
\text { Clinically significant tinnitus }\end{array}$ & Szumy uszne wymagające dalszej diagnostyki \\
\hline $\begin{array}{l}\text { Szumy uszne nieistotne klinicznie } \\
\text { Clinically non significant tinnitus }\end{array}$ & Szumy uszne niewymagające dalszej diagnostyki \\
\hline
\end{tabular}


występowaniem szumów usznych w populacji pediatrycznej i nieczęsto zgłaszanymi skargami próbuje się tłumaczyć tym, że dzieci doświadczając przez długi czas stałych szumów usznych, uznają je za zjawisko normalne. Dodatkowo jeśli któryś z członków rodziny, np. rodzic, odczuwa szumy uszne i komunikuje problem otoczeniu, to dziecko może uznać, że słyszenie szumów usznych czy też szumów w głowie jest zjawiskiem powszechnym, uznawanym za normę. Ponadto uważa się, że młodzi pacjenci, odczuwając szumy uszne, nie zdają sobie sprawy z faktu, że obecność tej dolegliwości ma istotne znaczenie medyczne $[24,25]$. Dzieci w przeciwieństwie do dorosłych potrafią łatwo odwrócić swoją uwagę od szumów usznych, gdyż angażują się mocno w odbiór bodźców ze środowiska zewnętrznego [26]. Baguley uważa, że dzieci nie zgłaszają szumów usznych, ponieważ nie osiągają takiego poziomu dojrzałości, aby podzielić się problemem $\mathrm{z}$ rówieśnikami, którzy często $\mathrm{w}$ tym wieku bywają niesympatyczni [24]. W trakcie realizacji przez Instytut Fizjologii i Patologii Słuchu badań oceniających występowanie szumów usznych u dzieci stwierdzono, że mniej niż połowa dzieci w wieku 7 i 12 lat (odpowiednio 44\% i $48 \%$ ) zgłasza słyszenie szumów usznych rodzicom [1].

Coelho podkreśla, że dziecko nie jest małym dorosłym, stąd reakcje na odczuwanie szumów mogą różnić się od tych prezentowanych przez osoby starsze [27]. Ważny - w kontekście różnic w powstawaniu szumów usznych u dzieci i osób dorosłych - wydaje się fakt, że droga słuchowa u dzieci jest bardziej plastyczna i dlatego bardziej podatna na działające szkodliwe biochemiczne czynniki zewnętrzne czy niekorzystny wpływ hałasu na narząd słuchu [28]. Ponadto pozawstęgowa droga słuchowa jest u dzieci zwykle aktywna, $\mathrm{u}$ dorosłych natomiast rzadko. Fakt ten może przyczynić się do wyjaśnienia różnic w mechanizmie generacji czy odczuwania szumów usznych w obu grupach [29].

\section{Epidemiologia szumów usznych u dzieci}

Odsetek dzieci dobrze słyszących odczuwających szumy uszne waha się od $6 \%$ do $27 \%$ [1,10,19,23,30-32]. Natomiast wśród dzieci $\mathrm{z}$ niedosłuchem szumy uszne występują u od 8,8\% do 58,6\% spośród nich [1,19,26,30,32-35]. Szeroki rozrzut wyników może wynikać z różnego wieku grup badanych, obejmujących dzieci w wieku od 6 do 18 lat. Sprawę dodatkowo komplikuje fakt, że w piśmiennictwie medycznym nie ma zgodności w definiowaniu pojęcia 'dziecko'. W Polsce wiek 18 lat uznaje się za początek okresu dorosłości, ale są kraje, gdzie dziecko, które ukończy 16 rok życia, uznawane jest już za osobę dorosłą. Różne definicje szumów usznych przyjęte przez badaczy, różna metodologia badań oraz odmienny sposób analizy statystycznej wyników to kolejne prawdopodobne przyczyny uzyskania tak szerokiego rozrzutu wyników.

\section{Ocena zależności pomiędzy występowaniem szumów usznych a wiekiem dziecka, płcią, współistniejącym niedosłuchem}

Większość autorów jest zgodnych, że ryzyko wystąpienia szumów usznych u dzieci wzrasta wraz $\mathrm{z}$ wiekiem dziecka $[1,10,19,27,33,36,37]$. Wyniki dotyczące występowania szumów usznych w zależności od płci dziecka są niejednoznaczne. Zdania autorów są podzielone.
Jedni badacze są zdania, że szumy uszne występują częściej u dziewcząt $[10,21,27,31]$, inni z kolei nie stwierdzili różnic w występowaniu szumów usznych w zależności od płci $[11,20,36]$. Większość autorów stoi na stanowisku, że szumy uszne występują częściej w grupie dzieci $\mathrm{z}$ niedosłuchem $\mathrm{w}$ porównaniu $\mathrm{z}$ dziećmi prawidłowo słyszącymi $[1,19,20,32,33,38,39]$. Jedynie Holgers nie stwierdziła istotnych zależności pomiędzy występowaniem szumów usznych i niedosłuchu [30]. Częstsze występowanie szumów usznych w grupie dzieci ze współistniejącą nadwrażliwością stwierdzili Bartnik, Baguley i Humphrriss $[8,20,39]$.

W badaniach oceniających zależności pomiędzy statusem ekonomicznym rodziny a częstością występowania szumów usznych stwierdzono mniejsze ryzyko wystąpienia szumów usznych u dzieci pochodzących $\mathrm{z}$ rodzin o wysokich dochodach $\mathrm{w}$ porównaniu $\mathrm{z}$ dziećmi $\mathrm{z}$ rodzin uzyskujących dochody niższe [10].

\section{Podsumowanie}

1. Odsetek dzieci prawidłowo słyszących, które odczuwają szumy uszne, waha się od $6 \%$ do $27 \%$. Z kolei $\mathrm{w}$ grupie dzieci niedosłyszących szumy uszne odczuwa od $8,8 \%$ do $58,6 \% \mathrm{z}$ nich. Do uzyskania tak szerokiego rozrzutu wyników przyczyniły się prawdopodobnie odmienne definicje szumów usznych, którymi się posługiwano, zbierając dane epidemiologiczne, różna metodologia badań oraz odmienny sposób analizy statystycznej wyników.

2. Szumy uszne mogą wpływać negatywnie na funkcjonowanie dziecka, powodując problemy ze snem, a w konsekwencji prowadzić do zaburzeń koncentracji i uzyskiwania gorszych wyników w nauce.

3. Szumy uszne u dzieci mogą powodować zaburzenia lękowe i depresyjne.

4. Częstość występowania szumów usznych wzrasta wraz $\mathrm{z}$ wiekiem dzieci.

5. Szumy uszne występują częściej u dzieci niedosłyszących oraz u dzieci z nadwrażliwością słuchową.

6. U dzieci pochodzących $\mathrm{z}$ rodzin o wysokich dochodach szumy uszne występują rzadziej.

7. Występowanie szumów usznych istotnych klinicznie wydaje się kryterium kwalifikującym dzieci do dalszej diagnostyki.

8. Podział szumów usznych dziecięcych na dokuczliwe i niedokuczliwe mógłby stanowić kryterium kwalifikujące do terapii po zakończonym procesie diagnostycznym.

9. Dzieci rzadko zgłaszają samoistnie szumy uszne, natomiast zapytane potrafią opowiedzieć o tym problemie. W przypadku dzieci powyżej 6 roku życia pytanie o obecność szumów usznych powinno zatem zostać włączone do rutynowego wywiadu audiologicznego czy laryngologicznego.

\section{Wnioski}

Szumy uszne u młodych pacjentów stanowią istotny problem, który wymaga opracowania jednolitego, przyjaznego dziecku i jego rodzicom, powszechnie obowiązującego schematu postępowania diagnostycznego i terapeutycznego. 


\section{Piśmiennictwo:}

1. Raj-Koziak D. Ocena częstości występowania szumów usznych u dzieci. Rozprawa doktorska, 2013: 42-46.

2. Beukes EW, Manchaiah V, Andersson G, Allen PM, Terlizzi PM, Baguley DM. Situationally influenced tinnitus coping strategies: a mixed methods approach. Disabil Rehabil, 2017: 1-11.

3. Mazurek B, Szczepek AJ, Brüggemann P. Tinnitus - clinical symptoms and therapy. Laryngorhinootologie, 2017; 96(1): 47-59.

4. Tunkel DE, Bauer CA, Sun GH, Rosenfeld RM, Chandrasekhar SS, Cunningham ER i wsp. Clinical practice guideline: Tinnitus. Otolaryngol. Head Neck Surg, 2014; 151(2 Suppl): 1-40.

5. Skarżyński H, Kukwa A, Chmielik M, Gryczyńska G, Grzegorowski M, Hassman-Poznańska E i wsp. Algorytm postępowania w przewlekłym wysiękowym zapaleniu ucha środkowego u dzieci. Audiofonologia, 1999(15): 63-68.

6. Skarżyński H, Miszka K, Zawadzki R, Mrówka M, Młotkowska-Klimek P, Wysocki J. Korelacja między przewlekłym wysiękowym zapaleniem ucha środkowego a przerostem migdałka gardłowego - analiza około 1500 przypadków. Audiofonologia, 2002; 22: 39-43.

7. Borowska B. Opracowanie procedury terapii szumów usznych u dzieci. Warszawa: Instytut Fizjologii i Patologii Słuchu, 2007.

8. Bartnik G, Stępień A, Raj-Koziak D i wsp. Troublesome tinnitus in children: epidemiology, audiological profile, and preliminary results of treatment. Int J Pediatr, 2012, 1-5.

9. Raj-Koziak D, Piłka A, Bartnik G, Fabijańska A, Kochanek K, Skarżyński H. The prevalence of tinnitus in 7-year-old children in the eastern of Poland. Otolaryngol Pol, 2011; 65(2): 106-109.

10. Mahboubi H, Oliaei S, Kiumehr S, Dwabe S, Djalilian HR. The prevalence and characteristics of tinnitus in the youth population of the United States. The Laryngoscope, 2013; 123(8): 2001-2008.

11. Savastano M. Characteristics of tinnitus in childhood. Eur J Pediatr, 2007; 166(8): 797-801.

12. Akagi H, Yuen K, Maeda Y, Fukushima K, Kariya S, Orita Y i wsp. Ménière's disease in childhood. Int J Pediatr Otorhinolaryngol, 2001; 61(3): 259-64.

13. Truy E, Furminieux V, Dubreuil C. Acoustic neuroma in children report of 5 cases. Ann Oto-Laryngol Chir Cervico Fac, 1999; 116(2): 92-97.

14. Fox GN, Baer MT. Palatal myoclonus and tinnitus in children. West J Med, 1991; 154(1): 98-102.

15. Jero J, Salmi T. Palatal myoclonus and clicking tinnitus in a 12year old girl-case report. Acta Oto-Laryngol Suppl, 2000; 543: 61-62.

16. Kutukcu Y, Imirzalioglu N, Odabasi Z, Gokcil Z, Vural O. Essential palatal myoclonus in monozygotic male twins. J Neurol, 2003; 250(7): 885-86.

17. MacDonald JT. Objective tinnitus due to essential palatal tremor in a 5-year old. Pediatr Neurol, 2007; 36(3): 175-76.

18. Howsam GD, Sharma A, Lambden SP, Fitzgerald J, Prinsley PR. Bilateral objective tinnitus secondary to congenital middle-ear myoclonus. J Laryngol Amp Otol, 2005; 119(6): 489-91.
19. Piotrowska A, Raj-Koziak D, Lorens A, Skarżyński H. Tinnitus reported by children aged 7 and 12 years. Int J Pediatr Otorhinolaryngol, 2015; 79(8): 1346-50.

20. Humphriss R, Hall AJ, Baguley DM. Prevalence and characteristics of spontaneous tinnitus in 11-year-old children. Int $\mathrm{J} \mathrm{Au}$ diol, 2016; 55(3): 142-48.

21. Holgers KM, Juul J. The suffering of tinnitus in childhood and adolescence. Int J Audiol, 2006; 45(5): 267-72.

22. Kentish RC, Crocker SR, McKenna L. Children's experience of tinnitus: a preliminary survey of children presenting to a psychology department. Br J Audiol, 2000; 34(6): 335-40.

23. Kim YH, Jung HJ, Kang SI, Park KT, Choi JS, Oh SH i wsp. Tinnitus in children: association with stress and trait anxiety. The Laryngoscope, 2012; 122(10): 2279-84.

24. Baguley DM, McFerran DJ. Tinnitus in childhood. Int J Pediatr Otorhinolaryngol, 1999; 49(2): 99-105.

25. Savastano M. A protocol of study for tinnitus in childhood. Int J Pediatr Otorhinolaryngol, 2002; 64(1): 23-27.

26. Viani LG. Tinnitus in children with hearing loss. J Laryngol Otol, 1989; 103(12): 1142-45.

27. Coelho CB, Sanchez TG, Tyler RS. Tinnitus in children and associated risk factors. Prog Brain Res, 2007; 166: 179-91.

28. Werner LA. The development of auditory behavior (or what the anatomists and physiologists have to explain). Ear Hear, 1996; 17(5): 438-46.

29. Moller AR, Rollins PR. The non-classical auditory pathways are involved in hearing in children but not in adults. Neurosci Lett, 2002; 319(1): 41-44.

30. Holgers K, Svedlund C. Tinnitus in childhood. J Psychosom Res, 2003; 55(2): 135

31. Park B, Choi HG, Lee H, An S, Kim SW, Lee JS i wsp. Analysis of prevalence of and risk factors for tinitus in a young population. Otol Neurotol, 2014; 35(7): 1218-22.

32. Juul J, Barrenäs ML, Holgers KM. Tinnitus and hearing in 7-year-old children. Arch Dis Child, 2012; 97(1): 28-30.

33. Nodar RH. Tinnitus aurium in school age children. J Aud Res, 1972(12): 133-35.

34. Graham JM. Tinnitus in children with hearing loss. Ciba Found Symp, 1981; 85: 172-92.

35. Stouffer JL, Tyler RS, Booth JC, Buckrell B. Tinnitus in normal hearing and hearing-impaired children. 1992.

36. Aksoy S, Akdogan O, Gedikli Y, Belgin E. The extent and levels of tinnitus in children of central Ankara. Int J Pediatr Otorhinolaryngol, 2007; 71(2): 263-68.

37. Raj-Koziak D. Występowanie szumów usznych u dzieci - przegląd piśmiennictwa. Now Audiofonol, 2016; 5(1): 1-6.

38. Coelho CB. Epidemiology of tinnitus in children. W: Moller AR, Langguth B, De Ridder D, Kleinjung T, red. Textbook of Tinnitus, 2011; 39-45.

39. Baguley DM, Bartnik G, Kleinjung T, Savastano M, Hough EA. Troublesome tinnitus in childhood and adolescence: Data from expert centres. Int J Pediatr Otorhinolaryngol, 2013; 77(2): $248-51$ 